\title{
MCH and apomorphine in combination enhance action potential firing of nucleus accumbens shell neurons in vitro
}

The MCH and dopamine receptor systems have been shown to modulate a number of behaviors related to reward processing, addiction, and neuropsychiatric conditions such as schizophrenia and depression. In addition, $\mathrm{MCH}$ and dopamine receptors can interact in a positive manner, for example in the expression of cocaine self-administration. A recent report (Chung et al., 2011) showed that the DA1/DA2 dopamine receptor activator apomorphine suppresses pre-pulse inhibition, a preclinical model for some aspects of schizophrenia. Importantly, MCH can enhance the effects of lower doses of apomorphine, suggesting that co-modulation of dopamine and $\mathrm{MCH}$ receptors might alleviate some symptoms of schizophrenia with a lower dose of dopamine receptor modulator and thus fewer potential side effects. Here, we investigated whether MCH and apomorphine could enhance action potential firing in vitro in the nucleus accumbens shell (NAshell), a region which has previously been shown to mediate some behavioral effects of MCH. Using whole-cell patch-clamp electrophysiology, we found that $\mathrm{MCH}$, which has no effect on firing on its own, was able to increase NAshell firing when combined with a subthreshold dose of apomorphine. Further, this $\mathrm{MCH} /$ apomorphine increase in firing was prevented by an antagonist of either a DA1 or a DA2 receptor, suggesting that apomorphine acts through both receptor types to enhance NAshell firing. The MCH/apomorphine-mediated firing increase was also prevented by an MCH receptor antagonist or a PKA inhibitor. Taken together, our results suggest that $\mathrm{MCH}$ can interact with lower doses of apomorphine to enhance NAshell firing, and thus that MCH and apomorphine might interact in vivo within the NAshell to suppress pre-pulse inhibition. 
F. Woodward Hopf ${ }^{\mathrm{a}^{*}}$, Taban Seif ${ }^{\mathrm{a}}$, Shinjae Chung ${ }^{\mathrm{b}}$, and Olivier Civelli ${ }^{\mathrm{c}}$

${ }^{a}$ Ernest Gallo Clinic and Research Center, Department of Neurology, University of California, San Francisco, 5858 Horton St., Suite 200, Emeryville, CA 94608, ${ }^{b}$ Department of Molecular and Cell Biology, Helen Wills Neuroscience Institute, University of California, Berkeley,

${ }^{\mathrm{c}}$ Departments of Pharmacology and Developmental and Cell Biology, University of California, Irvine, CA 92697

*Corresponding author: Email: woody@gallo.ucsf.edu, Phone: 510-985-3892, Fax:

510-985-3101 


\section{Introduction}

In addition to regulation of feeding, the melanin-concentrating hormone (MCH) system is an important regulators of a number of behaviors related to reward processing, addiction and other neuropsychiatric conditions such as schizophrenia and depression . The dopamine system also plays a key role in many addiction- and motivation-related behaviors and neuropsychiatric conditions . Interesting, dopamine receptors and $\mathrm{MCH}$ can interact positively in the regulation of some behaviors including in animal models of cocaine addiction and schizophrenia , while antagonistic interactions are also observed ( see also .

A recent study examined pre-pulse inhibition (PPI), where a startle response to an intense stimulus can be suppressed when a weak stimulus (the pre-pulse) immediately precedes the intense stimulus. The PPI is used as a measure of sensorimotor gating, and significant deficits in PPI are observed in patients with schizophrenia and some other neurological disorders, which may contribute to sensory overload and related symptoms (Braff et al. 2001). Chung et al. (2001a) found, in mice, that MCH had no effect alone on PPI but that MCH did enhance the ability of lower doses of the DA1/DA2 dopamine receptor agonist apomorphine to suppress PPI. One implication of this finding is that simultaneous modulation of $\mathrm{MCH}$ and dopamine receptors might represent a novel therapy for treatment of schizophrenia, which would allow use of lower doses of dopamine modulators and thus reduce unwanted side effects. However, to fully understand the mechanism of such an interaction, it would be useful to know which brain region these dopamine and $\mathrm{MCH}$ agents might interact within, which could suggest additional methods through which neurons targeted by dopamine and MCH could be modulated. Dopamine and $\mathrm{MCH}$ receptors are present in many brain regions , and thus the region within which apomorphine and MCH might interact to suppress PPI remains unclear. 
We previously used in vitro electrophysiology and biochemistry to show that MCH can interact cooperatively with dopamine receptor agonists to increase activity of nucleus accumbens (NAcb) shell (NAshell) medium spiny neurons. The NAshell is an important regulator of feeding, response to novelty, and some addiction- and reward-related behaviors including suppression of several forms of reward-related responding . In addition, the NAshell has been noted as a brain region which regulates PPI (Kodsi \& Swerdlow, 1997; Alsene et al. 2010), including where dopaminergic drugs can disrupt PPI (Devoto et al. 2011; Meyer \& Louilot 2011; but see Swerdlow et al. 2007), as well as other behavioral models considered to reflect symptoms of schizophrenia such as behavioral inflexibility (Floresco et al. 2009) and disturbances of latent inhibition (Murphy et al. 2000; Weiner 2003).

Here, we have investigated whether MCH interacts with apomorphine to increase in action potential (AP) firing in the NAshell in vitro, and examined which dopamine receptors might be required for this increase in activity. A cooperative interaction between $\mathrm{MCH}$ and apomorphine in vitro could suggest that the NAshell is a brain region where $\mathrm{MCH}$ and apomorphine interact to suppress PPI.

\section{Materials and Methods}

\section{Brain slice preparation and electrophysiology methods}

Male Sprague-Dawley rats (p21-35) were deeply anesthetized with pentobarbital (100 mg/kg, i.p.) in accordance with Institutional Animal Care and Use and National Institutes of Health Guidelines and under the guidance and approval of the IACUC Committee of the Ernest Gallo Clinic and Research Center. Transcardial perfusion was performed with $15 \mathrm{ml}$ of ice-cold sucrose-aCSF (in mM: 75 sucrose, $87 \mathrm{NaCl}, 2.5 \mathrm{KCl}, 1.25 \mathrm{NaH}_{2} \mathrm{PO}_{4}, 7 \mathrm{MgCl}_{2}, 0.5 \mathrm{CaCl}_{2}, 25$ $\mathrm{NaHCO}_{3}, 1$ ascorbic acid) saturated with $95 \% \mathrm{O}_{2}$ and $5 \% \mathrm{CO}_{2}$. The brain was rapidly removed 
and coronal slices $(300 \mu \mathrm{m})$ were cut in this same sucrose-aCSF. Slices were transferred to the recovery chamber containing aCSF (in mM: $126 \mathrm{NaCl}, 2.5 \mathrm{KCl}, 1.2 \mathrm{NaH}_{2} \mathrm{PO}_{4}, 1.2 \mathrm{MgCl}_{2}, 2.4$ $\mathrm{CaCl}_{2}, 18 \mathrm{NaHCO}_{3}, 11$ glucose, with $\mathrm{pH}$ 7.2-7.4 and mOsm 304-306) at $31^{\circ} \mathrm{C}$ and saturated with 95\% $\mathrm{O}_{2}$ and 5\% $\mathrm{CO}_{2} .1 \mathrm{mM}$ ascorbic acid was added to the aCSF in the recovery chamber just before adding the slices. Slices were incubated for 30 min-5 hr prior to recordings.

Whole-cell current-clamp recordings were made from NAshell medium spiny neurons, identified as previously described . Patch-clamping was performed as described using 3-5 M $\Omega$ glass electrodes filled with a potassium methanesulfonate-based internal solution (130 mM KOH, 105 mM methanesulfonic acid, 17 mM hydrochloric acid, 20 mM HEPES, 0.2 mM EGTA, 2.8 mM NaCl, 2.5 mg/ml MgATP, 0.25 mg/ml NaGTP, pH 7.2-7.4, 275-285 mOsm). Patch-clamp data were collected at $15 \mathrm{KHz}$ and filtered at $2 \mathrm{KHz}$ using Clampex 9.2 or 10 and a Multiclamp 700A patch amplifier (Axon Instruments, Union City, CA). During electrophysiology experiments, slices were submerged and continuously perfused (using a peristaltic pump, $2.5 \mathrm{ml} / \mathrm{min}$ ) with carbogen-bubbled aCSF warmed to $31-32^{\circ} \mathrm{C}$, and supplemented with DNQX (10 $\mu \mathrm{M}$, to block AMPA receptors) and picrotoxin (50 $\mu \mathrm{M}$, to block GABA-A receptors). Here, we decided to use a concentration of $2 \mu \mathrm{M} \alpha$-flupenthixol, a D1/D2 receptor antagonist. Previous reports have reported divergent concentrations of $\alpha$-flupenthixol in slice experiments (10 $\mu \mathrm{M}$ in Cameron \& Williams 1993, $0.1 \mu \mathrm{M}$ in Benardo \& Prince 1982). Also, behavioral experiments injecting $\alpha$-flupenthixol into the NAcb tend to use higher

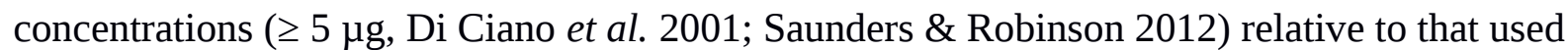
for SCH23390 or raclopride (1-2 $\mu \mathrm{g}$, see Yun et al. 2004). Thus, we chose $2 \mu \mathrm{M}$, which is somewhat higher than the $1 \mu \mathrm{M}$ we use for SCH23390 and raclopride in vitro. In addition, $\alpha$-flupenthixol had no effect of firing on its own (Fig. 2C, $-0.3 \pm 2.3 \%$ change in firing versus 
basal, $P=0.116$ paired t-test), in agreement with our previous studies that blockers more selective for D1 or D2 receptors have no effect on firing on their own in the NAshell (Hopf et al. 2003).

\section{AP Generation, Analyses and Statistics}

The resting membrane potential was determined just after breaking into a neuron, and each neuron was then brought to a resting potential of $\sim-85 \mathrm{mV}$ by passage of $\mathrm{DC}$ current via the patch amplifier before further firing experiments. To generate APs, neurons in current clamp were depolarized with a series of 7 or 8500 -msec current pulses, with 20 pA between each current pulse, and where the initial current pulse for each neuron was just sub-threshold for firing. This series of current pulses was applied every 30 sec throughout the experiment, and was alternated with hyperpolarizing steps (-50 and $-100 \mathrm{pA})$ to examine input resistance.

To analyze changes in firing for each cell, a depolarizing step was chosen that gave 6-7 APs in the basal condition. We then determined the number of APs at this current step at all time points during the experiment for that cell. The baseline firing rate was determined from the average of firing in the 4 minutes before addition of apomorphine $\pm \mathrm{MCH}$, and was normalized to $100 \%$ for each cell. The percent change in firing versus baseline was then determined by taking the average of firing during the 6th-8th minute of apomorphine $\pm \mathrm{MCH}$ exposure. Statistics across groups were determined using these averaged values for the peak change in firing. Thus, a one-way ANOVA was calculated comparing $3 \mu \mathrm{M}$ apomorphine+MCH with and without dopamine or MCH receptor blockers, and also comparing with $3 \mu \mathrm{M}$ apomorphine alone; Tukey was used as a post-hoc. $P<0.05$ was taken to indicate significant differences. Data are shown as mean $+/$ - SEM. 


\section{Results}

To examine whether apomorphine and $\mathrm{MCH}$ interacted in vitro to alter AP firing in NAshell neurons, we performed in vitro whole-cell patch-clamp electrophysiology experiments in brain slices containing NAshell medium spiny neurons. A series of 500 msec depolarizing steps of varying current intensity were applied every 30 sec (see Methods) to generate AP firing. As shown in Figure 1A,B, $3 \mu \mathrm{M}$ apomorphine did not enhance NAshell firing on its own (n = 7, $0.2 \pm 3.8 \%$ change in firing versus basal), although $10 \mu \mathrm{M}$ apomorphine was sufficient to enhance firing (Fig. 1C, $24.2 \pm 8.4 \%$ change in firing versus basal, $\mathrm{n}=7$, paired t-test $P=0.021$ baseline versus $10 \mu \mathrm{M}$ apomorphine). In contrast, $3 \mu \mathrm{M}$ apomorphine significantly enhanced firing when combined with $1 \mu \mathrm{M}$ MCH (Fig. 1A,B, $\mathrm{n}=7,24.4 \pm 7.8 \%$ change in firing versus basal, $P<0.01$ versus $3 \mu \mathrm{M}$ apomorphine alone). We also found that $1 \mu \mathrm{M} \mathrm{MCH}$ in combination with $10 \mu \mathrm{M}$ apomorphine significantly increased firing (Fig. 1D, $n=5,29.5 \pm 6.3$ \% change in firing versus basal, $P=0.010$ paired t-test). $1 \mu \mathrm{M} \mathrm{MCH}$ in combination with $1 \mu \mathrm{M}$ apomorphine did not change firing (Fig. $1 \mathrm{E}, n=6,0.7 \pm 2.8 \%$ change in firing versus basal, $P=$ 0.798 paired t-test), suggesting that a minimal amount of dopamine receptor activation was required to interact with $\mathrm{MCH}$ to increase NAshell firing. Previous studies have shown that $\mathrm{MCH}$ either does not increase firing or reduces firing in the NAshell when applied alone; in either case it does not enhance NAshell firing when applied alone. Thus, our results suggest that $\mathrm{MCH}$ can interact with a sub-threshold dose of apomorphine $(3 \mu \mathrm{M})$ to increase NAshell firing in vitro.

Since our experiments were performed in the presence of DNQX to inhibit spontaneous AMPA receptor activation and picrotoxin to inhibit spontaneous $\mathrm{GABA}_{\mathrm{A}}$ receptor activation 
(Hopf et al. 2003; 2005), we next examined whether $3 \mu \mathrm{M}$ apomorphine in combination with 1 $\mu \mathrm{M} \mathrm{MCH}$ increased firing in the absence of these blockers, which might reflect more physiological conditions. As shown in Figure 1F, apomorphine+MCH did significantly enhance firing under conditions where AMPA and $\mathrm{GABA}_{\mathrm{A}}$ receptors were not blocked $(n=5,30.3 \pm 9.6$ $\%$ change in firing versus basal, $P=0.030$ paired t-test), suggesting that the ability of apomorphine $+\mathrm{MCH}$ to enhance firing persisted even when $\mathrm{AMPA}$ and $\mathrm{GABA}_{\mathrm{A}}$ receptors could be modulated by possible dopaminergic effects on spontaneous release (Nicola \& Malenka 1997; but see Ortinski et al. 2012) or spontaneous activity of GABA interneurons (Centonze et al. 2003).

A number of studies suggest that PKA is an central regulator of NAcb dopaminergic signaling (Svenningsson et al. 2004) including dopamine receptor enhancement of NAshell firing (Hopf et al. 2003). In agreement, the increase in firing with $3 \mu \mathrm{M}$ apomorphine $+\mathrm{MCH}$ was prevented by including the PKA inhibitor peptide PKI (20 $\mu \mathrm{M}$, Hopf et al. 2005) in the intracellular pipette solution (Fig. 1G; $n=5,2.1 \pm 5.1 \%$ change in firing versus basal, $P=0.030$ vs no PKI in Fig. 1B).

We next determined whether the apomorphine+MCH increase in firing required dopamine type 1 (DA1) and/or dopamine type 2 (DA2) receptors. Application of $3 \mu \mathrm{M}$ apomorphine+MCH did not increase firing after 10 min pre-exposure to a receptor blocker for DA1 receptors (Fig. 2A, SCH23390 $1 \mu \mathrm{M}, \mathrm{n}=5,-3.9 \pm-2.2 \%$ change in firing versus basal), a blocker for DA2 receptors (Fig. 2B, raclopride $1 \mu \mathrm{M}, \mathrm{n}=6,-0.1 \pm 8.2 \%$ change in firing versus basal) or a blocker that targets both DA1 and DA2 receptors (Fig. 2C, $\alpha$-flupenthixol $2 \mu \mathrm{M}, \mathrm{n}=$ 4, $-4.2 \pm 3.4 \%$ change in firing versus basal). The increase in NAshell with $3 \mu \mathrm{M}$ apomorphine+MCH was also prevented by pre-exposure to the $\mathrm{MCH}$ receptor inhibitor TPI (2 
$\mu \mathrm{M}$, (Fig. 2D, $\mathrm{n}=6,3.0 \pm 2.4 \%$ change in firing versus basal), confirming the importance of $\mathrm{MCH}$ receptors in the action of apomorphine $+\mathrm{MCH}$. A one-way ANOVA comparing the groups shown in Figure 3 found a significant effect across groups $(F(5,29)=4.140, P=0.006)$, and post-hoc analyses showed that the $3 \mu \mathrm{M}$ apomorphine+MCH enhancement in firing was significantly prevented by pre-exposure to any of the four receptor blockers tested here $(P<$ 0.05). Together, these results suggest that $\mathrm{MCH}$ in combination with $3 \mu \mathrm{M}$ apomorphine was able to enhance firing in NAshell neurons, and that this increase in firing required activity at both DA1 and DA2 receptors as well as MCH receptors and PKA.

To further explore the mechanism underlying the apomorphine/MCH increase in firing, we analyzed the input resistance and several aspects of the action potential waveform from all agonist conditions that enhanced action potential firing (Table 1). In agreement with our previous work (Hopf et al. 2003), increases in firing with apomorphine/MCH were not accompanied by any changes in these parameters, suggesting that the apomorphine/MCH increase in firing did not reflect alterations in inward rectifying channels or sodium or fast potassium channels active during an action potential (Hopf et al. 2003; 2010b).

\section{Discussion}

Using in vitro whole-cell patch-clamp electrophysiology, we found that $\mathrm{MCH}$ and apomorphine in combination enhanced firing of NAshell neurons; an increase in firing was not observed with this concentration of apomorphine on its own, and $\mathrm{MCH}$ alone was previously shown not to increase NAshell firing . We also found that the increase in NAshell firing with apomorphine+MCH was inhibited by antagonists of either DA1, DA2, or MCH receptors or by 
an agent that blocks both DA1 and DA2 receptors. These results concur with our previous findings that DA1 and DA2 receptors interact to enhance NAshell activity (see also in the NAcb core and , and suggest that apomorphine enhancement of firing requires both DA1 and DA2 receptors in addition to an interaction with $\mathrm{MCH}$ receptors. The apomorphine+MCH increase in firing was prevented by a PKA inhibitor, consistent with previous work showing that PKA is an important mediator of NAcb dopaminergic signaling involving DA1 receptors (Svenningsson et al. 2004), including dopamine receptor enhancement of NAshell firing (Hopf et al. 2003). Our results also suggest that the NAshell may represent the brain region where lower doses of apomorphine can interact with MCH in vivo to suppress PPI .

We previously showed that MCH in combination with both DA1 and DA2 receptor agonists significantly enhanced NAshell firing in vitro , but we did not determine whether DA1 or DA2 might itself be sufficient to interact with $\mathrm{MCH}$ to enhance firing. Thus, the present results with DA receptor antagonists provide new information that apomorphine activation of both DA1 and DA2 receptors was required for apomorphine to interact with $\mathrm{MCH}$ to enhance firing. This agrees with our previous work that dopamine enhancement of firing can be prevented by either DA1 or DA2 receptor antagonists . We should note that the DA1 receptor blocker SCH23390 has been shown to directly inhibit GIRK channels (Kuzhikandathil \& Oxford 2002). However, when acting through this mechanism, SCH23390 directly depolarizes cells and enhances action potential firing; we observed no effect of SCH23390 alone on firing in a previous study (Hopf et al. 2003) or here with a shorter baseline period before adding SCH23390, suggesting that SCH23390 did not directly alter GIRK function under the conditions studied here. 
Our results suggesting a DA1/DA2 interaction to increase firing also agree with a larger behavioral literature that has shown that a number of behaviors are mediated through a DA1/DA2 interaction in the NAcb (e.g. , and for cocaine-primed reinstatement and intra-NAshell self-administration of dopamine receptor activators , DA1 and DA2 receptors interact cooperatively to support behavior. In contrast, some behaviors are regulated differentially by DA1 and DA2 receptors in the NAcb ; at a cellular level, DA1 and DA2 receptors can have divergent effects, e.g., on glutamate receptor function . Here, we found that apomorphine $+\mathrm{MCH}$ increased firing when $\mathrm{AMPA}$ and $\mathrm{GABA}_{\mathrm{A}}$ receptors were not blocked pharmacologically, suggesting that the increase in firing still occurred in the presence of any possible dopaminergic effects on glutamate or $\mathrm{GABA}_{\mathrm{A}}$ receptors due to spontaneous release (Nicola \& Malenka 1997; but see Ortinski et al. 2012) or spontaneous activity of GABAergic interneurons (Centonze et al. 2003). Although the mechanism through which DA1 and DA2 receptors in the NAcb might interact positively under some conditions remain unclear, studies have described a mechanism requiring DA1-DA2 heterodimers or G protein beta-gamma subunits and PKA.

We should also note that studies of MCH alone on NAshell activity have yielded somewhat mixed results. We found that MCH alone did alter neuronal firing or the levels of phospho-DARPP but that MCH in combination with dopamine receptor agonists enhanced both measures . In contrast, Sears and colleagues found that $\mathrm{MCH}$ alone can inhibit firing and phospho-GluR1 in the NAshell. Although the reason for these mixed results is not completely apparent, it is possible that MCH would be able to increase firing when combined with activation of dopamine receptors but have different effects on firing when applied alone. Such divergent 
effects of receptor agonists alone versus in combination with other types of receptor agonists has previously been shown, for example as shown with adenosine/cannabinoid receptor interactions .

\section{Conclusion}

We found that MCH interacted with subthreshold levels of the dopamine receptor agonist apomorphine to enhance firing of NAshell neurons in vitro. Apomorphine+MCH enhancement of NAshell firing required both DA1 and DA2 receptors as well as MCH receptors. Our in vitro results parallel what is observed in vivo where $\mathrm{MCH}$ enhances the ability of lower doses of apomorphine to suppress PPI, an animal model for some aspects of schizophrenia in humans. Thus, the NAshell may represent the brain region where $\mathrm{MCH}$ and apomorphine interact to regulate the expression of PPI and thus could regulate some symptoms of human schizophrenia. Apomorphine within the NAshell can also reduce withdrawal-related anxiety, suggesting that this mechanism might be relevant to other psychiatric diseases such as depression which are modulated through MCH .

\section{Acknowledgements}

This work was supported by the DA024746 (OC, FWH) and DA028065 (TS). The authors declare no conflicts of interest. FWH and TS conducted the experiments. FWH, TS, SC, and OC contributed to the rationale and design of the experiments and the preparation of the manuscript. All authors approved the final article.

\section{References}


Alsene KM, Fallace K, Bakshi VP. 2010. Ventral striatal noradrenergic mechanisms contribute to sensorimotor gating deficits induced by amphetamine. Neuropsychopharmacology 35:2346-2356.

Benardo LS, Prince DA. 1982. Dopamine action on hippocampal pyramidal cells. Journal of Neuroscience 2:415-423.

Bernal SY, Dostova I, Kest A, Abayev Y, Kandova E, Touzani K, Sclafani A, Bodnar RJ. 2008. Role of dopamine D1 and D2 receptors in the nucleus accumbens shell on the acquisition and expression of fructose-conditioned flavor-flavor preferences in rats. Behavioral Brain Research 190:59-66.

Besson M, Belin D, McNamara R, Theobald DE, Castel A, Beckett VL, Crittenden BM, Newman AH, Everitt BJ, Robbins TW, Dalley JW. 2010. Dissociable control of impulsivity in rats by dopamine $\mathrm{d} 2 / 3$ receptors in the core and shell subregions of the nucleus accumbens. Neuropsychopharmacology 35:560-569.

Braff DL, Geyer MA, Swerdlow NR. 2001. Human studies of prepulse inhibition of startle: normal subjects, patient groups, and pharmacological studies. Psychopharmacology 156:234-258.

Cameron DL, Williams JT. 1993. Dopamine D1 receptors facilitate transmitter release. Nature 366:344-347.

Centonze D, Grande C, Usiello A, Gubellini P, Erbs E, Martin AB, Pisani A, Tognazzi N, Bernardi G, Moratalla R, Borrelli E, Calabresi P.2003. Receptor subtypes involved in the presynaptic and postsynaptic actions of dopamine on striatal interneurons. Journal of Neuroscience 23:6245-6254. 
Chung S, Hopf FW, Nagasaki H, Li CY, Belluzzi JD, Bonci A, Civelli O. 2009. The melanin-concentrating hormone system modulates cocaine reward. Proceedings of the National Academy of Sciences U S A 106:6772-6777.

Chung S, Parks GS, Lee C, Civelli O. 2011b. Recent updates on the melanin-concentrating hormone $(\mathrm{MCH})$ and its receptor system: lessons from MCH1R antagonists. Journal of Molecular Neuroscience 43:115-121.

Chung S, Verheij MM, Hesseling P, van Vugt RW, Buell M, Belluzzi JD, Geyer MA, Martens GJ, Civelli O. 2011a. The melanin-concentrating hormone (MCH) system modulates behaviors associated with psychiatric disorders. PLoS One 6:e19286.

Devoto P, Frau R, Bini V, Pillolla G, Saba P, Flore G, Corona M, Marrosu F, Bortolato M. 2012. Inhibition of $5 \alpha$-reductase in the nucleus accumbens counters sensorimotor gating deficits induced by dopaminergic activation. Psychoneuroendocrinology 37:1630-1645.

Di Chiara G. 2002. Nucleus accumbens shell and core dopamine: differential role in behavior and addiction. Behavioral Brain Research 137:75-114.

Di Ciano P. 2008. Distinct contributions of dopamine receptors in the nucleus accumbens core or shell to established cocaine reinforcement under a second-order schedule. European Neuropsychopharmacology 18:888-896.

Di Ciano P, Cardinal RN, Cowell RA, Little SJ, Everitt BJ. 2001. Differential involvement of NMDA, AMPA/kainate, and dopamine receptors in the nucleus accumbens core in the acquisition and performance of pavlovian approach behavior. Journal of Neuroscience 21:9471-9477.

Floresco SB, Zhang Y, Enomoto T. 2009. Neural circuits subserving behavioral flexibility and their relevance to schizophrenia. Behavioral Brain Research 204:396-409. 
Georgescu D, Sears RM, Hommel JD, Barrot M, Bolanos CA, Marsh DJ, Bednarek MA, Bibb JA, Maratos-Flier E, Nestler EJ, DiLeone RJ. 2005. The hypothalamic neuropeptide melanin-concentrating hormone acts in the nucleus accumbens to modulate feeding behavior and forced-swim performance. Journal of Neuroscience 25:2933-2940.

Ghazizadeh A, Ambroggi F, Odean N, Fields HL. 2012. Prefrontal cortex mediates extinction of responding by two distinct neural mechanisms in accumbens shell. Journal of Neuroscience 32:726-737.

Goto Y, Grace AA. 2005. Dopaminergic modulation of limbic and cortical drive of nucleus accumbens in goal-directed behavior. Nature Neuroscience 8:805-812.

Haluk DM, Floresco SB. 2009. Ventral striatal dopamine modulation of different forms of behavioral flexibility. Neuropsychopharmacology 34:2041-2052.

Hasbi A, O'Dowd BF, George SR. 2011. Dopamine D1-D2 receptor heteromer signaling pathway in the brain: emerging physiological relevance. Molecular Brain 4:26.

Hopf FW, Bowers MS, Chang SJ, Chen BT, Martin M, Seif T, Cho SL, Tye K, Bonci A. 2010a. Reduced nucleus accumbens SK channel activity enhances alcohol seeking during abstinence. Neuron 65:682-694.

Hopf FW, Cascini MG, Gordon AS, Diamond I, Bonci A. 2003. Cooperative activation of dopamine D1 and D2 receptors increases spike firing of nucleus accumbens neurons via G-protein betagamma subunits. Journal of Neuroscience 23:5079-5087.

Hopf FW, Mailliard WS, Gonzalez GF, Diamond I, Bonci A. 2005. Atypical protein kinase C is a novel mediator of dopamine-enhanced firing in nucleus accumbens neurons. Journal of Neuroscience 25:985-989. 
Hopf FW, Seif T, Mohamedi ML, Chen BT, Bonci A. 2010b. The small-conductance calcium-activated potassium channel is a key modulator of firing and long-term depression in the dorsal striatum. European Journal of Neuroscience 31:1946-1959.

Ikemoto S, Glazier BS, Murphy JM, McBride WJ. 1997. Role of dopamine D1 and D2 receptors in the nucleus accumbens in mediating reward. Journal of Neuroscience 17:8580-8587.

Inoue Y, Yao L, Hopf FW, Fan P, Jiang Z, Bonci A, Diamond I. 2007. Nicotine and ethanol activate protein kinase A synergistically via G(i) betagamma subunits in nucleus accumbens/ventral tegmental cocultures: the role of dopamine $\mathrm{D}(1) / \mathrm{D}(2)$ and adenosine A(2A) receptors. Journal of Pharmacology and Experimental Therapeutics 322:23-29.

Kodsi MH, Swerdlow NR. 1997. Reduced prepulse inhibition after electrolytic lesions of nucleus accumbens subregions in the rat. Brain Research 773:45-52.

Kuzhikandathil EV, Oxford GS. 2002. Classic D1 dopamine receptor antagonist R-(+)-7-chloro-8-hydroxy-3-methyl-1-phenyl-2,3,4,5-tetrahydro-1H-3-benzazepine hydrochloride (SCH23390) directly inhibits G protein-coupled inwardly rectifying potassium channels. Molecular Pharmacology 62:119-126.

LaLumiere RT, Smith KC, Kalivas PW. 2012. Neural circuit competition in cocaine-seeking: roles of the infralimbic cortex and nucleus accumbens shell. European Journal of Neuroscience 35:614-622.

Meyer FF, Louilot A. 2011. Latent inhibition-related dopaminergic responses in the nucleus accumbens are disrupted following neonatal transient inactivation of the ventral subiculum. Neuropsychopharmacology 36:1421-1432.

Missale C, Nash SR, Robinson SW, Jaber M, Caron MG. 1998. Dopamine receptors: from structure to function. Physiological Reviews 78:189-225. 
Morganstern I, Chang GQ, Chen YW, Barson JR, Zhiyu Y, Hoebel BG, Leibowitz SF. 2010. Role of melanin-concentrating hormone in the control of ethanol consumption: Region-specific effects revealed by expression and injection studies. Physiology and Behavior 101:428-437.

Mul JD, la Fleur SE, Toonen PW, Afrasiab-Middelman A, Binnekade R, Schetters D, Verheij MM, Sears RM, Homberg JR, Schoffelmeer AN, Adan RA, DiLeone RJ, De Vries TJ, Cuppen E. 2011. Chronic loss of melanin-concentrating hormone affects motivational aspects of feeding in the rat. PLoS One 6:e19600.

Murphy CA, Pezze M, Feldon J, Heidbreder C. 2000. Differential involvement of dopamine in the shell and core of the nucleus accumbens in the expression of latent inhibition to an aversively conditioned stimulus. Neuroscience 97:469-477.

Nestler EJ, Carlezon WA, Jr. 2006. The mesolimbic dopamine reward circuit in depression. Biological Psychiatry 59:1151-1159.

Nicola SM, Malenka RC. 1997. Dopamine depresses excitatory and inhibitory synaptic transmission by distinct mechanisms in the nucleus accumbens. Journal of Neuroscience 17:5697-5710.

Nowend KL, Arizzi M, Carlson BB, Salamone JD. 2001. D1 or D2 antagonism in nucleus accumbens core or dorsomedial shell suppresses lever pressing for food but leads to compensatory increases in chow consumption. Pharmacology Biochemistry and Behavior 69:373-382.

Ortinski PI, Vassoler FM, Carlson GC, Pierce RC. 2012. Temporally dependent changes in cocaine-induced synaptic plasticity in the nucleus accumbens shell are reversed by D1-like dopamine receptor stimulation. Neuropsychopharmacology 37:1671-1682. 
Pezze MA, Dalley JW, Robbins TW. 2007. Differential roles of dopamine D1 and D2 receptors in the nucleus accumbens in attentional performance on the five-choice serial reaction time task. Neuropsychopharmacology 32:273-283.

Radke AK, Gewirtz JC. 2012. Increased Dopamine Receptor Activity in the Nucleus Accumbens Shell Ameliorates Anxiety during Drug Withdrawal. Neuropsychopharmacology.

Saito Y, Cheng M, Leslie FM, Civelli O. 2001. Expression of the melanin-concentrating hormone (MCH) receptor mRNA in the rat brain. Journal of Comparative Neurology 435:26-40.

Saunders BT, Robinson TE. 2012. The role of dopamine in the accumbens core in the expression of Pavlovian-conditioned responses. European Journal of Neuroscience 36:2521-2532.

Schmidt HD, Pierce RC. 2006. Cooperative activation of D1-like and D2-like dopamine receptors in the nucleus accumbens shell is required for the reinstatement of cocaine-seeking behavior in the rat. Neuroscience 142:451-461.

Sears RM, Liu RJ, Narayanan NS, Sharf R, Yeckel MF, Laubach M, Aghajanian GK, DiLeone RJ. 2010. Regulation of nucleus accumbens activity by the hypothalamic neuropeptide melanin-concentrating hormone. Journal of Neuroscience 30:8263-8273.

Seif T, Makriyannis A, Kunos G, Bonci A, Hopf FW. 2011. The endocannabinoid 2-arachidonoylglycerol mediates D1 and D2 receptor cooperative enhancement of rat nucleus accumbens core neuron firing. Neuroscience 193:21-33.

Shin R, Qin M, Liu ZH, Ikemoto S. 2008. Intracranial self-administration of MDMA into the ventral striatum of the rat: differential roles of the nucleus accumbens shell, core, and olfactory tubercle. Psychopharmacology 198:261-270.

Shirayama Y, Chaki S. 2006. Neurochemistry of the nucleus accumbens and its relevance to depression and antidepressant action in rodents. Current Neuropharmacology 4:277-291. 
Svenningsson P, Nishi A, Fisone G, Girault JA, Nairn AC, Greengard P. 2004. DARPP-32: an integrator of neurotransmission. Annual Reviews of Pharmacology Toxicology 44:269-296.

Swerdlow NR, Shoemaker JM, Bongiovanni MJ, Neary AC, Tochen LS, Saint Marie RL. 2007. Strain differences in the disruption of prepulse inhibition of startle after systemic and intra-accumbens amphetamine administration. Pharmacology Biochemistry and Behavior 87:1-10.

Tebano MT, Martire A, Popoli P. 2012. Adenosine A(2A)-cannabinoid CB(1) receptor interaction: An integrative mechanism in striatal glutamatergic neurotransmission. Brain Research, epub ahead of print.

Tyhon A, Lakaye B, Adamantidis A, Tirelli E. 2008. Amphetamine- and cocaine-induced conditioned place preference and concomitant psychomotor sensitization in mice with genetically inactivated melanin-concentrating hormone $\mathrm{MCH}(1)$ receptor. European Journal of Pharmacology 599:72-80.

Wang W, Dever D, Lowe J, Storey GP, Bhansali A, Eck EK, Nitulescu I, Weimer J, Bamford NS. 2012. Regulation of prefrontal excitatory neurotransmission by dopamine in the nucleus accumbens core. Journal of Physiology, epub ahead of print.

Weiner I. 2003. The "two-headed" latent inhibition model of schizophrenia: modeling positive and negative symptoms and their treatment. Psychopharmacology 169:257-297.

Wise RA. 2008. Dopamine and reward: the anhedonia hypothesis 30 years on. Neurotoxicology Research 14:169-183. 
Yun IA, Wakabayashi KT, Fields HL, Nicola SM. 2004. The ventral tegmental area is required for the behavioral and nucleus accumbens neuronal firing responses to incentive cues. Journal of Neuroscience 24:2923-1933. 
Table 1. Enhancement of firing with apomorphine $+/-\mathrm{MCH}$ was not accompanied by changes in input resistance (Rinput) or several action potential waveform parameters ( $P$ value for paired t-test comparisons between values at baseline and values after addition of apomorphine +/$\mathrm{MCH})$. Analyses were only performed under conditions where firing was enhanced.

"Apo3+MCH without blockers" indicates experiments where Apo3+MCH was added in the absence of picrotoxin and DNQX. "AP” indicates action potential, and waveform parameters were determined as previously described (Hopf et al. 2003, 2010b). Although there is some variability among groups in terms of basal input resistance, a one-way ANOVA found no differences in basal input resistance across the four groups tested $(F(3,20)=1.102, P=0.372)$.

\begin{tabular}{|c|c|c|c|c|c|c|c|c|}
\hline Measure & Basal & $\begin{array}{c}\text { Apo3+ } \\
\text { MCH }\end{array}$ & Basal & Apo10 & Basal & $\begin{array}{c}\text { Apo10+ } \\
\text { MCH }\end{array}$ & Basal & $\begin{array}{c}\text { Apo3+MCH } \\
\text { without } \\
\text { blockers }\end{array}$ \\
\hline $\begin{array}{l}\text { Rinput } \\
(\mathrm{M} \Omega)\end{array}$ & $\begin{array}{r}174.6 \\
\pm 21.4\end{array}$ & $\begin{array}{c}184.6 \\
\pm 21.0 \\
P=0.083\end{array}$ & $\begin{array}{r}158.7 \\
\pm 28.0\end{array}$ & $\begin{array}{c}164.1 \\
\pm 31.3 \\
P=0.345\end{array}$ & $\begin{array}{r}127.8 \\
\pm 16.8\end{array}$ & $\begin{array}{c}143.8 \\
\pm 18.4 \\
P=0.149\end{array}$ & $\begin{array}{c}126.8 \\
\pm 14.8\end{array}$ & $\begin{array}{c}129.9 \\
\pm 14.7 \\
P=0.554\end{array}$ \\
\hline $\begin{array}{l}\text { AP } \\
\text { amplitude } \\
\text { (mV) }\end{array}$ & $\begin{array}{l}80.9 \\
\pm 2.5\end{array}$ & $\begin{array}{c}78.8 \\
\pm 3.6 \\
P=0.168\end{array}$ & $\begin{array}{l}79.1 \\
\pm 1.6\end{array}$ & $\begin{array}{c}78.7 \\
\pm 1.5 \\
P=0.583 \\
\end{array}$ & $\begin{array}{l}82.4 \\
\pm 3.1\end{array}$ & $\begin{array}{c}80.8 \\
\pm 4.7 \\
P=0.430\end{array}$ & $\begin{array}{r}78.8 \\
\pm 2.5\end{array}$ & $\begin{array}{c}77.4 \\
\pm 3.6 \\
P=0.083 \\
\end{array}$ \\
\hline $\begin{array}{l}\text { AP } \\
\text { threshold } \\
\text { (mV) }\end{array}$ & $\begin{array}{l}-45.5 \\
\pm 1.7\end{array}$ & $\begin{array}{c}-46.2 \\
\pm 2.3 \\
P=0.343\end{array}$ & $\begin{array}{l}-47.3 \\
\pm 2.3\end{array}$ & $\begin{array}{c}-48.1 \\
\pm 2.5 \\
P=0.097\end{array}$ & $\begin{array}{l}-46.2 \\
\pm 1.2\end{array}$ & $\begin{array}{c}-47.7 \\
\pm 1.1 \\
P=0.077\end{array}$ & $\begin{array}{l}-44.6 \\
\pm 2.6\end{array}$ & $\begin{array}{c}-45.5 \\
\pm 2.4 \\
P=0.182 \\
\end{array}$ \\
\hline $\begin{array}{l}\text { AP } \\
\text { half-width } \\
\text { (ms) }\end{array}$ & $\begin{array}{c}1.85 \\
\pm 0.16\end{array}$ & $\begin{array}{c}1.79 \\
\pm 0.09 \\
P=0.523 \\
\end{array}$ & $\begin{array}{c}1.77 \\
\pm 0.09\end{array}$ & $\begin{array}{c}1.83 \\
\pm 0.08 \\
P=0.319\end{array}$ & $\begin{array}{c}1.77 \\
\pm 0.06\end{array}$ & $\begin{array}{c}1.82 \\
\pm 0.09 \\
P=0.278 \\
\end{array}$ & $\begin{array}{c}1.83 \\
\pm 0.11\end{array}$ & $\begin{array}{c}1.82 \\
\pm 0.13 \\
P=0.983\end{array}$ \\
\hline $\begin{array}{l}\text { Peak of } \\
\text { the fast } \\
\text { AHP } \\
(\mathrm{mV})\end{array}$ & $\begin{array}{l}-59.5 \\
\pm 2.3\end{array}$ & $\begin{array}{c}-59.8 \\
\pm 3.0 \\
P=0.700\end{array}$ & $\begin{array}{l}-63.1 \\
\pm 1.5\end{array}$ & $\begin{array}{c}-63.3 \\
\pm 1.6 \\
P=0.603\end{array}$ & $\begin{array}{l}-60.3 \\
\pm 1.8\end{array}$ & $\begin{array}{c}-61.4 \\
\pm 1.9 \\
P=0.240\end{array}$ & $\begin{array}{l}-58.3 \\
\pm 3.1\end{array}$ & $\begin{array}{c}-58.5 \\
\pm 3.0 \\
P=0.449\end{array}$ \\
\hline
\end{tabular}

\section{Figure Legends}


Fig. 1. $(\boldsymbol{A}, \boldsymbol{B})(\boldsymbol{A})$ Example traces and $(\boldsymbol{B})$ grouped data across time showing that $1 \mu \mathrm{M} \mathrm{MCH}$ (MCH) and $3 \mu \mathrm{M}$ apomorphine (Apo3) interact to enhance firing in NAshell neurons in vitro, while $3 \mu \mathrm{M}$ apomorphine had no effect alone. (C) $10 \mu \mathrm{M}$ apomorphine (Apo10) was sufficient to enhance NAshell firing. (D) $1 \mu \mathrm{M} \mathrm{MCH}$ in combination with $10 \mu \mathrm{M}$ apomorphine significantly increased firing. (E) $1 \mu \mathrm{M} \mathrm{MCH}$ in combination with $1 \mu \mathrm{M}$ apomorphine did not increase firing. (F) $3 \mu \mathrm{M}$ apomorphine in combination with $1 \mu \mathrm{M} \mathrm{MCH}$ significantly enhanced firing under conditions where AMPA and $\mathrm{GABA}_{\mathrm{A}}$ receptors were not blocked. (G) $3 \mu \mathrm{M}$ apomorphine $+1 \mu \mathrm{M}$ MCH did not increase firing when the PKA inhibitor peptide PKI (20 $\mu \mathrm{M})$ was included in the intracellular pipette.

Fig. 2. Enhancement of NAshell firing by $\mathrm{MCH}(1 \mu \mathrm{M})+$ apomorphine $(3 \mu \mathrm{M})$ was prevented by pre-exposure to $(\boldsymbol{A})$ the DA1 receptor blocker SCH23390 (SCH, $1 \mu \mathrm{M})$, (B) the DA2 receptor blocker raclopride (Racl, $1 \mu \mathrm{M}),(\boldsymbol{C})$ the D1/D2 blocker $\alpha$-flupenthixol (flupen, $2 \mu \mathrm{M})$, or $(\boldsymbol{D})$ the MCH receptor blocker TPI $(2 \mu \mathrm{M})$.

Fig. 3. Significant effect $(* P<0.05)$ of $\mathrm{MCH}+$ apomorphine $(3 \mu \mathrm{M})$ versus $3 \mu \mathrm{M}$ apomorphine alone or versus $\mathrm{MCH}+3 \mu \mathrm{M}$ apomorphine after pre-exposure to antagonists for DA1 (SCH), DA2 (Racl), DA1/DA2 (flupen) or MCH (TPI) receptors. 
Figure 1

Increased NAshell firing with apomorphine and $\mathrm{MCH}$ 


\section{Hopf et al., Figure 1}

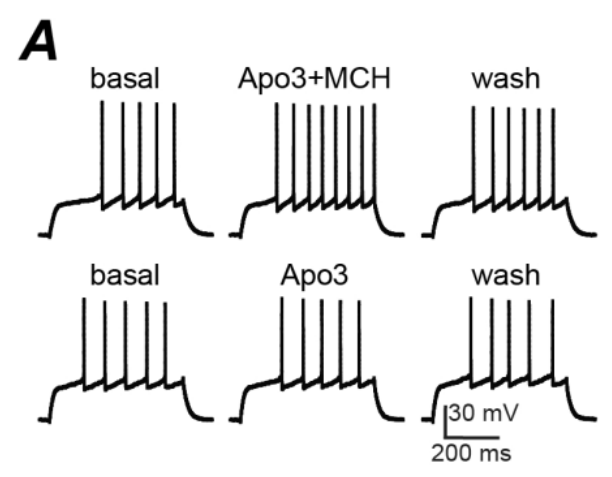

B
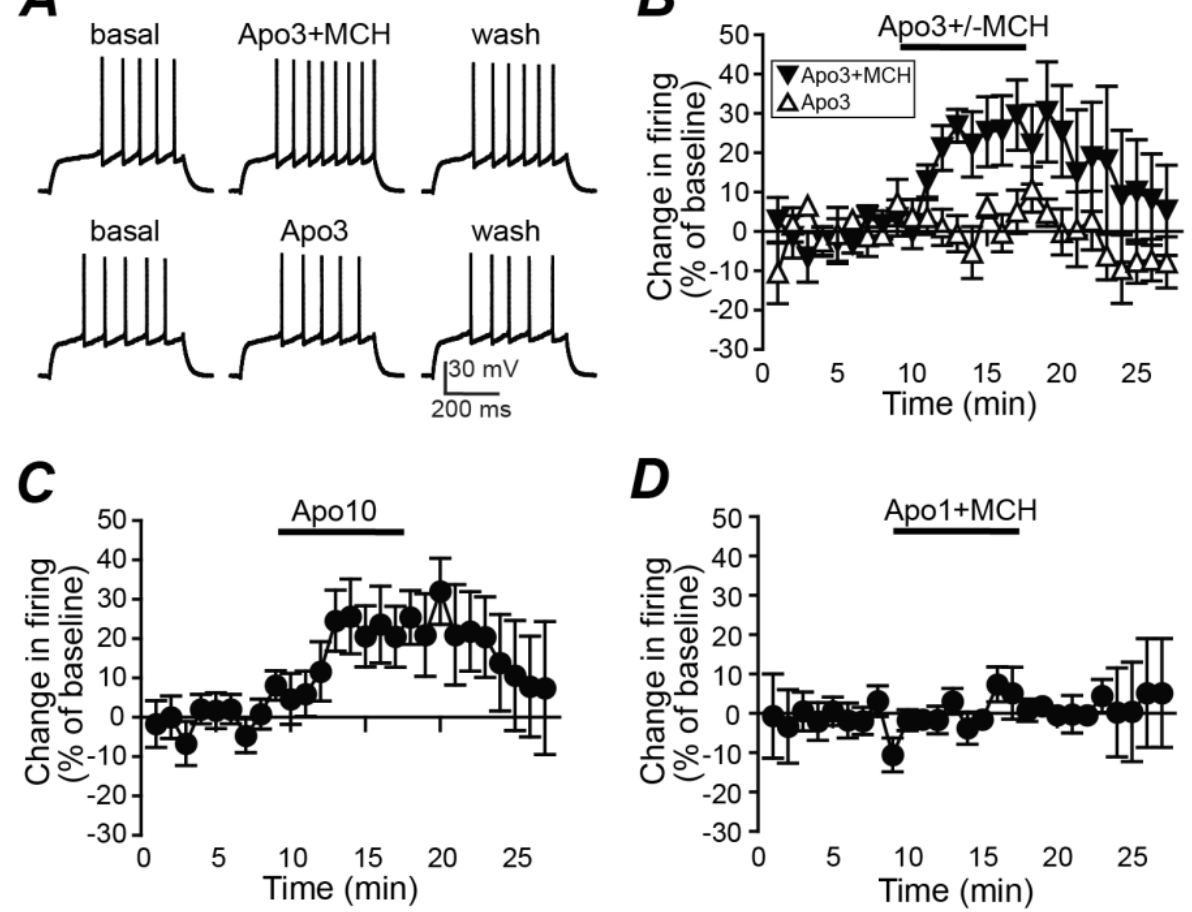

D ${ }_{50} \quad$ Apo1+MCH
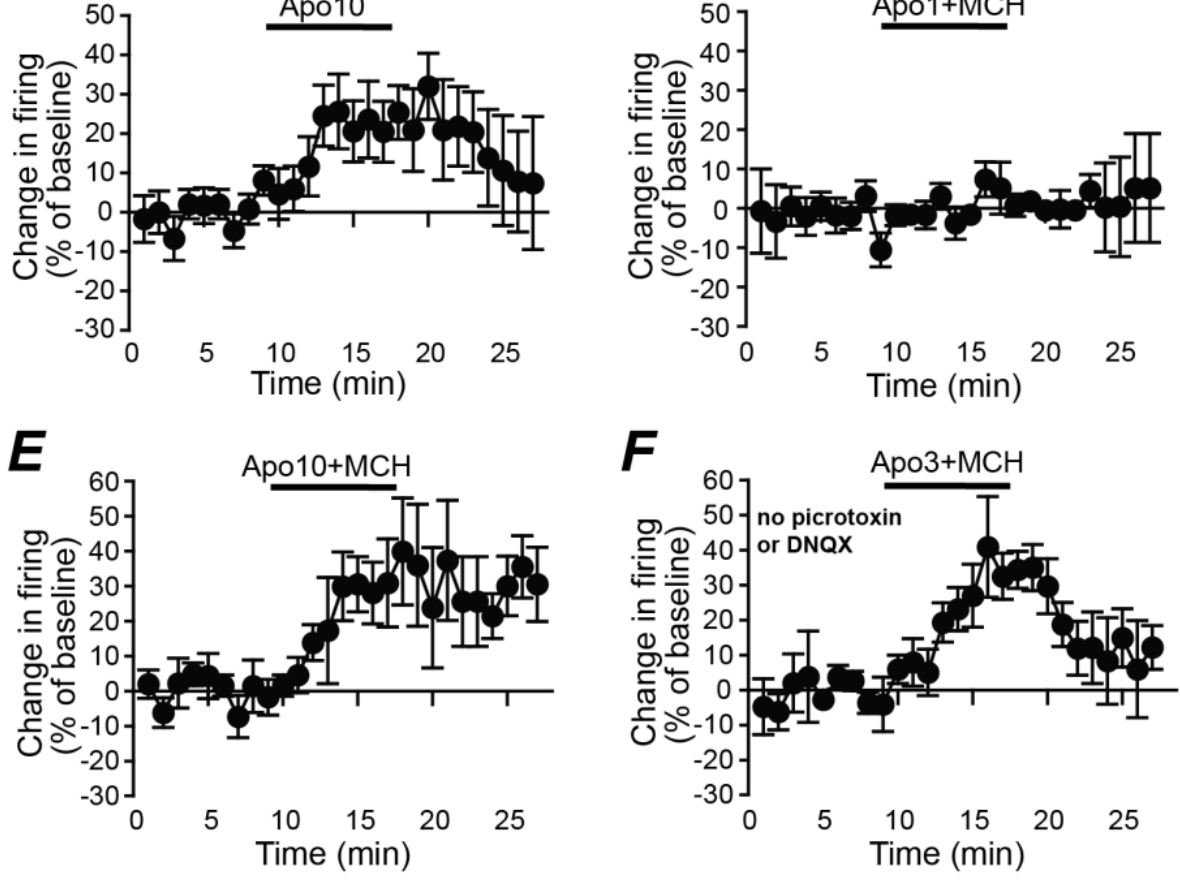

G

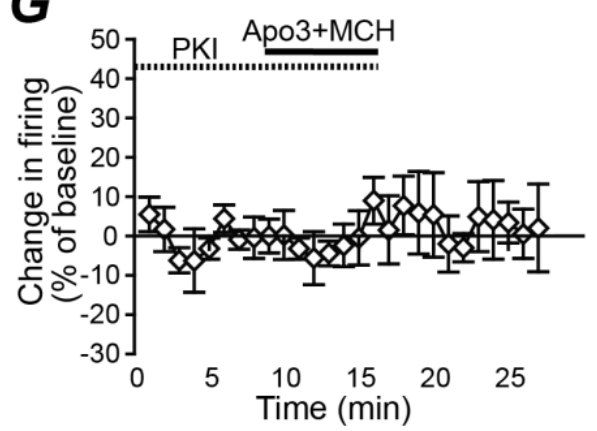




\section{Figure 2}

Dopamine receptor inhibitors prevent the apomorphine/MCH enhancement of firing

\section{Hopf et al., Figure 2}
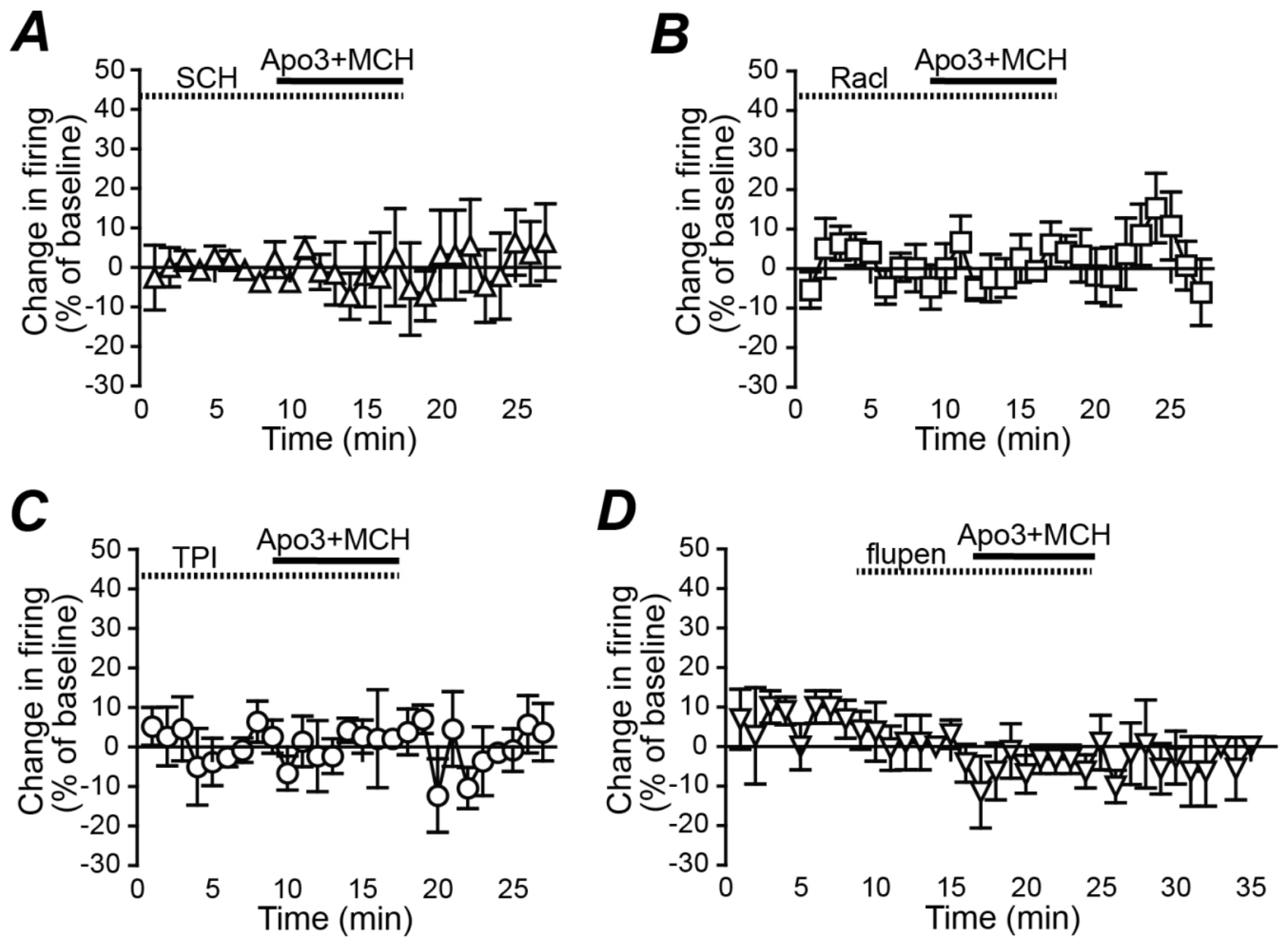


\section{Figure 3}

ANOVA for dopamine receptor mediation of apomorphine/MCH enhancement of firing 


\section{Hopf et al., Figure 3}

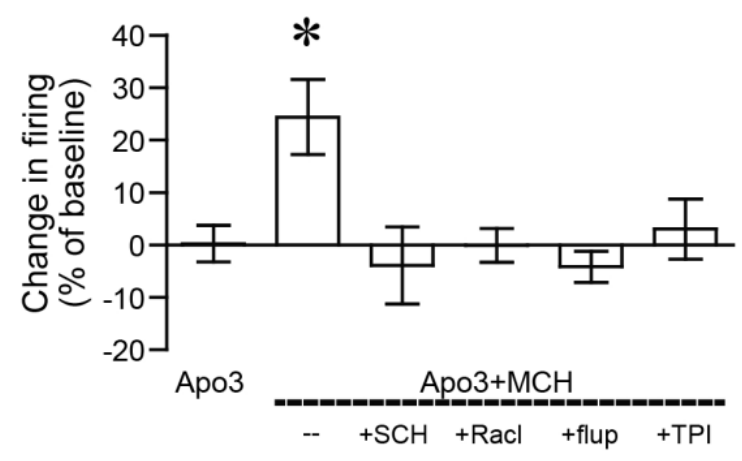

